\title{
Bacteriology and tear protein profiles of the dry eye
}

\author{
D V SEAL, ${ }^{1}$ J I McGILL ${ }^{2}$ I A MACKIE,${ }^{3}$ G M LIAKOS,${ }^{2}$ P JACOBS, ${ }^{4}$ AND \\ N J GOULDING ${ }^{4}$
}

From the 'Department of Microbiology, Northwick Park Hospital and Clinical Research Centre, Harrow, Middlesex; ' Southampton Eye Hospital, Southampton; the ${ }^{3}$ Department of Ophthalmology, St George's Hospital, London SW17; and the ${ }^{4}$ Department of Microbiology, Southampton General Hospital, Southampton

SUMmARY The concentrations of tear lysozyme, lactoferrin, ceruloplasmin, IgA, and IgG have been estimated in patients with dry eyes at the same time as semiquantitative bacterial culture was performed of the conjunctivae and lids. Staphylococcal isolations were quantified and biotyped. There was no increased conjunctival colonisation by any particular biotype of Staphylococcus aureus or Staph. epidermidis, and similar numbers of conjunctivae were sterile as in controls $(33 \%)$; neither were any pathogens such as pneumococci or haemophili isolated. We consider that the conjunctiva of the dry eye, without the lacrimal secretion components of lysozyme and lactoferrin, has an alternative protective antibacterial mechanism which is derived from serum proteins via chronically inflamed vessels.

The dry eye is often considered to be infected with staphylococci, ${ }^{1}$ partly because they are easy to culture from the lids and conjunctivae ${ }^{2}$ and partly because of reduced amounts of tear lysozyme being present. However, the normal eye is usually colonised with certain types of staphylococci, so that commensals need to be distinguished from those with a pathogenic role. Different subtypes of staphylococci have recently been investigated in both normal persons and patients with chronic blepharitis by a semiquantitative culture technique. ${ }^{3}$ Certain biotypes of staphylococci were shown to exist in large numbers on normal lids and conjunctivae while only $33 \%$ of normal conjunctivae sampled were sterile. This same technique has now been used to culture organisms from patients with either keratoconjunctivitis sicca or 'questionably dry' eyes in order to investigate how the bacterial flora differs in these patients from that of normal persons and whether it relates to altered concentrations of lysozyme, lactoferrin, ceruloplasmin, or immunoglobulins found in their tears.

\section{Patients and methods}

Results from 66 normal volunteers, aged $20-80$ and previously described, ${ }^{34}$ have been compared with

Correspondence to Dr D V Seal, Department of Microbiology, Northwick Park Hospital, Watford Road, Harrow, Middlesex HA1 3UJ. those from patients. Both groups were sampled for tear proteins and microbial culture over the same period by identical techniques. Both eyes were sampled of six patients with well established keratoconjunctivitis sicca, as were both eyes of 13 patients who were considered 'questionably dry' and who also had reduced levels of tear lysozyme and lactoferrin.

The bacteriological sampling technique has been described previously ${ }^{3}$ together with the simple BairdParker scheme used to subdivide Staphylococcus epidermidis isolates into five biotypes. The enzymelinked immunosorbent assay (ELISA) method developed to measure the concentration of the various tear proteins has also been given, ${ }^{3}$ as well as the effect of age on normal levels. ${ }^{4}$ This has allowed us to compare the tear protein concentrations for each patient with expected normal values for that age.

\section{Results}

TEAR PROTEIN PROFILES

In the sicca patients both tear lysozyme and lactoferrin concentrations were more than 2 standard deviations below the mean of normal persons $(p<0.05)$, while the ceruloplasmin concentration was significantly increased $(p<0.05)$ above normal in six out of 12 eyes (Fig. 1). Amounts of IgA were in the low normal range, and were reduced below 2 standard deviations from the mean in three out of 12 eyes, while IgG was greatly increased in eight out 

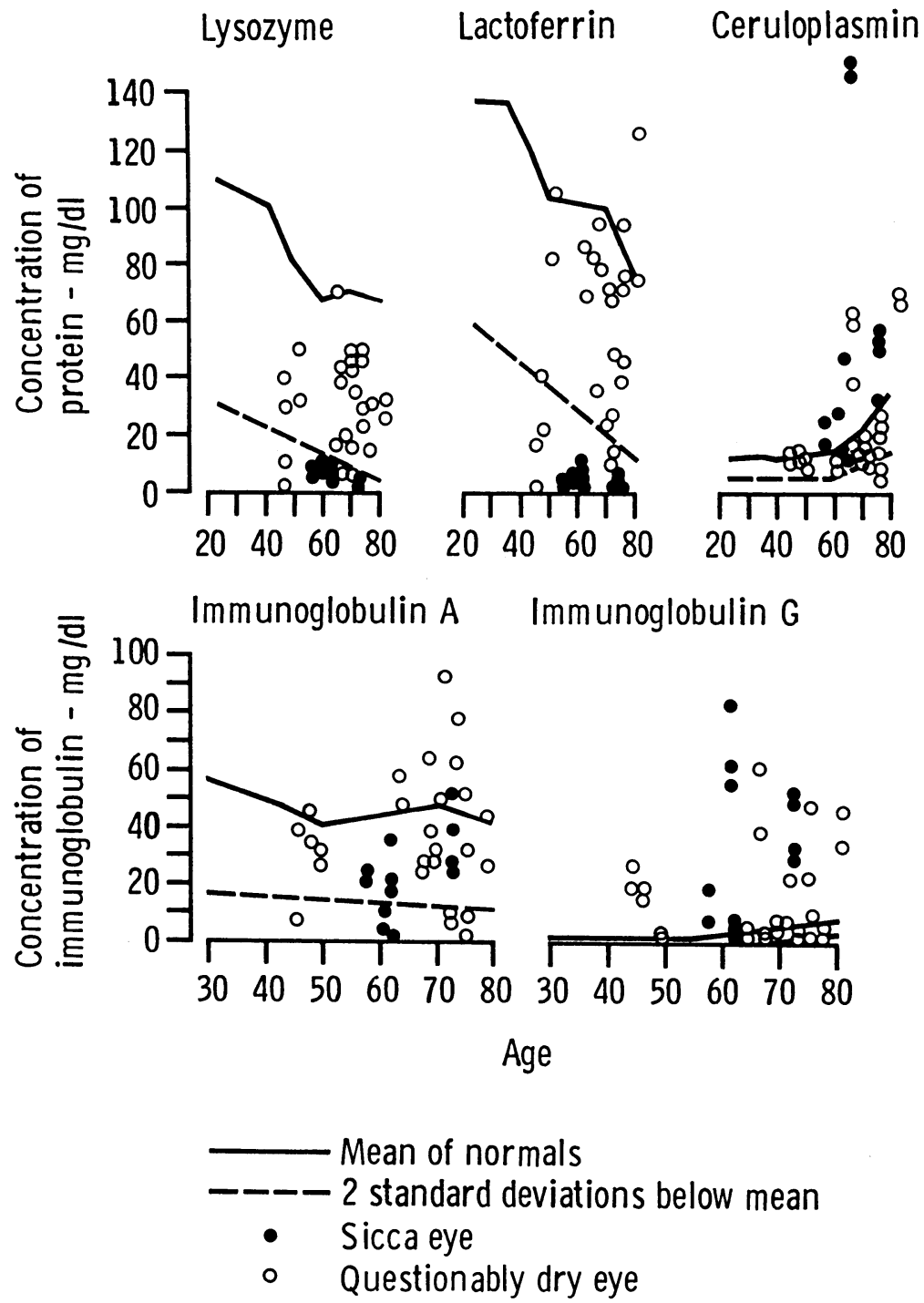

Fig. 1 Tear protein levels in sicca and questionably dry eyes. (SI conversion: $\mathrm{mg} / d l \times 0 \cdot 01=\mathrm{g} / 1$ ).

of 12 eyes. In the patients with 'questionably dry' eye both tear lysozyme and lactoferrin were in the low normal range, and significantly low $(\mathrm{p}<0.05)$ in four and five eyes respectively (Fig. 1). The tear ceruloplasmin concentrations were in the normal range except in two eyes greater than 2 standard deviations from the normal mean and two eyes below this limit. The IgA was within the normal range except in five eyes greater than 2 standard deviations below the mean. IgG was found in the normal range for 15 eyes but significantly raised $(p<0.05)$ for 11 eyes.

\section{BACTERIOLOGY}

Results of bacterial isolations from lids and conjunctivae are given qualitatively in Table 1 and quantitatively, for staphylococcal isolates, in Table 2. They show that a heavy growth of Staph. aureus was present in only one patient (both eyes) but not in others, while there was little difference with Staph. epidermidis between the patients and normal persons.

\section{Discussion}

The reduction found in tear lysozyme concentration in the patients with dry eye confirms earlier work. ${ }^{1}$ This decrease parallels the severity of the condition, so that in patients with severely dry eye the lysozyme concentration falls to zero. A similar reduction has been demonstrated for lactoferrin, whose correlation with lysozyme is impressive. Such correlation has 
Table 1 Percentage isolations of bacterial flora from each group

\begin{tabular}{|c|c|c|c|c|c|c|}
\hline & \multicolumn{2}{|c|}{$\begin{array}{l}\text { Normal eyes* } \\
(n=66)\end{array}$} & \multicolumn{2}{|c|}{$\begin{array}{l}\text { Sicca eyes } \\
(n=12)\end{array}$} & \multicolumn{2}{|c|}{$\begin{array}{l}\text { Questionably dry eyes } \\
(n=26)\end{array}$} \\
\hline & $\begin{array}{l}\text { Lid } \\
\%\end{array}$ & $\begin{array}{l}\text { Conj. } \\
\%\end{array}$ & $\begin{array}{l}\text { Lid } \\
\%\end{array}$ & $\begin{array}{l}\text { Conj. } \\
\%\end{array}$ & $\begin{array}{l}\text { Lid } \\
\%\end{array}$ & $\begin{array}{l}\text { Conj. } \\
\%\end{array}$ \\
\hline Staph. aureus (type I) & 5 & 2 & 17 & 17 & 0 & 0 \\
\hline Staph. epidermidis (type II/III) & 47 & 33 & 67 & 25 & 65 & 31 \\
\hline Staph. epidermidis (type VI) & 6 & 2 & 25 & 0 & 4 & 0 \\
\hline Micrococcus & 21 & 5 & 0 & 0 & 8 & 0 \\
\hline Diphtheroids & 31 & 18 & 17 & 0 & 8 & 0 \\
\hline Str. pneumoniae & 0 & 0 & 0 & 0 & 0 & 0 \\
\hline Str. viridans & 0 & 0 & 0 & 0 & 8 & 8 \\
\hline Neisseria sp. & 5 & 2 & 0 & 8 & 12 & 0 \\
\hline Haemophilus sp. & 2 & 0 & 0 & 0 & 0 & 0 \\
\hline Coliforms & 5 & 0 & 0 & 0 & 0 & 0 \\
\hline No growth & 17 & 33 & 0 & 25 & 12 & 58 \\
\hline
\end{tabular}

* Seal et al. ${ }^{3}$

also been found by Janssen and van Bijsterveld, using polyacrylamide-gel electrophoresis. ${ }^{5}$ In an earlier study ${ }^{4}$ we found a correlation between amounts of lysozyme and lactoferrin, also assayed by ELISA, at $r=0.60(p<0.01)$ in the normal eye. The combined reduction of lysozyme and lactoferrin, both potent antibacterial proteins, could be considered to compromise the eye, increasing the risk of local infection. However, we found greatly increased tear IgG in 19 out of 38 eyes examined and increased tear ceruloplasmin in eight eyes. IgA levels were reduced in only eight eyes. The increased ceruloplasmin concentra- tion may be due to tear concentration as well as its secretion from chronically inflamed conjunctival vessels. Increased tear IgG is probably from the same source, and, while complement components were not assayed, they can be expected to be increased as well.

The various antibacterial roles of these inhibitors in biological secretions have been reviewed, ${ }^{6}$ and complement and IgG have been shown to have definite antibacterial activity, but conditions like the dry eye were not considered. However, these conditions can be produced experimentally now that the concentrations of each protein are known. They

Table 2 Quantitative bacteriology results for staphylococci isolated from lids and conjunctivae

\begin{tabular}{|c|c|c|c|c|c|c|}
\hline & \multicolumn{6}{|c|}{$\%$ Isolations in each group } \\
\hline & \multicolumn{2}{|c|}{$\begin{array}{l}\text { Normal eyes* } \\
(n=66)\end{array}$} & \multicolumn{2}{|c|}{$\begin{array}{l}\text { Sicca eyes } \\
(n=12)\end{array}$} & \multicolumn{2}{|c|}{$\begin{array}{l}\text { Questionably dry eyes } \\
(n=26)\end{array}$} \\
\hline & Lid & Conj. & Lid & Conj. & Lid & Conj. \\
\hline \multicolumn{7}{|c|}{ Staph. aureus (type I) } \\
\hline$+1-$ & 5 & 2 & 0 & 0 & 0 & 0 \\
\hline+ & 0 & 0 & 0 & 0 & 0 & 0 \\
\hline++ & 0 & 0 & 17 & 17 & 0 & 0 \\
\hline \multicolumn{7}{|c|}{ Staph. epidermidis (type II/III) } \\
\hline$+1-$ & 3 & 12 & $\mathbf{0}$ & 0 & 12 & 8 \\
\hline+ & 33 & 21 & 33 & 25 & 38 & 23 \\
\hline++ & 11 & 2 & 42 & 0 & 15 & 0 \\
\hline \multicolumn{7}{|c|}{ Staph. epidermidis (type IV/V) } \\
\hline$+1-$ & 0 & 5 & 0 & 9 & 12 & 4 \\
\hline+ & 6 & 9 & 17 & 9 & 19 & 4 \\
\hline++ & 2 & $\mathbf{0}$ & 0 & 0 & 8 & 0 \\
\hline \multicolumn{7}{|c|}{ Staph. epidermidis (type VI) } \\
\hline$+1-$ & 6 & 0 & 25 & $\mathbf{0}$ & 0 & 0 \\
\hline+ & 0 & 2 & 0 & 0 & 0 & 0 \\
\hline++ & 0 & 0 & 0 & 0 & $\mathbf{0}$ & 0 \\
\hline
\end{tabular}

${ }^{*}$ Seal et al. ${ }^{3}$ 
could then be tested for bacterial inhibition against isolates from a patient's lid flora with dilutions of the patient's own serum as a source of IgG antibody and complement, to mimic secretion from inflamed vessels. If it can be shown that these components, IgG and complement, have antibacterial activity against lid isolates, then this would support our hypothesis that in the patient with dry eye these components replace the antibacterial activity of the decreased levels of lysozyme and lactoferrin.

Bacteriological assessment of the conjunctiva is best performed by a semiquantitative method.' However, any method is slightly affected by 'sample error' when collections are made from the eye unless a biopsy is taken and processed whole, but that of Cagle and Abshire is worthy of consideration. ${ }^{8}$ They sampled conjunctivae with soluble alginate swabs which they then dissolved in a measured volume of buffer so as to gain a numerical count. They then compared a test result with an expected numerical value for normal flora. While this must be considered ideal for investigating an individual patient, particularly for chronic staphylococcal infection, it is not necessary when a pathogen such as pneumococcus is isolated which is known to be absent from the uninfected eye. However, their method can be usefully applied to the investigation of chronic infection in a dry eye, particularly to distinguish between staphylococcal colonisation and infection. Differentiation of Staph. epidermidis into separate biotypes is also useful. We have used the British classification system, based on Baird-Parker (1963), as opposed to the American system, based on Kloos and Schleifer (1975); both have been reviewed and compared recently by Marples. ${ }^{9}$

Our qualitative results show that the conjunctivae were sterile by our culture methods in $33 \%$ of normal eyes, $25 \%$ of sicca eyes, and $58 \%$ of 'questionably dry' eyes. In those patients from whom bacteria were isolated there were no pathogens such as Streptococcus pneumoniae, or Haemophilus influenzae. There was no difference between normal persons and patients in the conjunctival isolation rates of Staph. epidermidis types II/III, IV/V, and VI, which thus colonise the conjunctivae of dry eyes in the same amounts as normal eyes. The lid flora differed in siccas eyes, with Staph. aureus being present as a heavy growth in only one patient, but without pus being present, compared with none in the normal persons, and with Staph. epidermidis type II/III being present as a heavy growth in $\mathbf{4 2} \%$ compared with $11 \%$ in normal persons. However, in another study this type (II/III) was not found to be associated with chronic non-ulcerative blepharitis. ${ }^{3}$ The reason for increased numbers of Staph. epidermidis type II/III in the lids of sicca patients is not clear, but a heavy growth did not occur on the conjunctivae. We have thus found little evidence to support either Staph. aureus or Staph. epidermidis being more pathogenic in the dry than the normal eye.

Janssen and van Bijsterveld have recently investigated various tear proteins in their patients with dry eye and found similar reductions in lysozyme and lactoferrin. They too recorded very few clinical infections in 300 of their patients but did not carry out bacteriological studies. ${ }^{10}$ This supports our hypothesis that there is local antibacterial activity in the conjunctiva of the patient with dry eye.

We thank Professor P Watt, Department of Microbiology, Southampton Medical School, for his helpful advice and use of facilities, Dr R Marples and Dr Jean Dolby for their advice, and Miss Daksha Badiani for technical assistance. Wessex RHA is thanked for a grant for NJG.

\section{References}

1 Mackie IA, Seal DV. The questionably dry eye. Br J Ophthalmol 1981; 65: 2-9.

2 Perkins RE, Kundsin RB, Pratt MV, Abrahamsen I, Leibowitz HM. Bacteriology of normal and infected conjunctiva. J Clin Microbiol 1975; 1: 147-9.

3 Seal DV, McGill JI, Liakos GM, Jacobs P, Goulding N. Microbial and immunological investigations of chronic nonulcerative blepharitis and meibomianitis. $\mathrm{Br} J$ Ophthalmol 1985; 69: 604-11.

4 McGill JI, Liakos GM, Goulding N, Seal DV. Normal tear protein profiles and age-related changes. Br J Ophthalmol 1984; 68: $316-20$

5 Janssen PT, van Bijsterveld OP. The relations between tear fluid concentrations of lysozyme, lactoferrin and tear-specific prealbumin. Exp Eye Res 1983; 36: 773-6.

6 Reiter R. Bacterial inhibitors in milk and other biological secretions, with special reference to the complement/antibody, transferrin/lactoferrin and lactoperoxidase/thiocyanate/hydrogen peroxide systems. In: Skinner FA, Hugo WB, eds. Inhibition and inactivation of vegetative microbes. London: Academic Press, 1976.

7 Jones DB, Liesegang TJ, Robinson NM. Laboratory diagnosis of ocular infections. In: Washington JA, ed. Cumulative techniques and procedures in clinical microbiology (Cumitech), Number 13. Washington, DC: American Society for Microbiology, 1981.

8 Cagle GD, Abshire RL. Quantitative ocular bacteriology: a method for the enumeration and identification of bacteria from the skin-lash margin and conjunctiva. Invest Ophthalmol Vis Sci 1981; 20: 751-7.

9 Marples RR. Taxonomic studies of staphylococci and micrococci. In: Jeljaszewicz J, ed. Staphylococci and staphylococcal infections. Zentralbl Bakteriol Microbiol Hyg (A) suppl. 10. Stuttgart and New York: Fischer, 1981.

10 Janssen PT, van Bijsterveld OP. Local antibacterial defense in the sicca syndrome. In: Holly FJ, ed. The preocular tear film-health, disease and contact lens wear. Lubbock, Texas: Dry Eye Institute Publication, 1985.

Accepted for publication 17 June 1985. 